\title{
All our yesterdays: a hydrological retrospective
}

\author{
Jim McCulloch \\ Burcot Tower, Abingdon, Oxon OX14 3DJ, UK \\ E-mail: jsgmhess@aol.com
}

\begin{abstract}
This paper traces the development and eventual recognition of hydrology as a scientific subject in its own right in the UK and, later, in the European Geophysical Society (EGS), now the European Geosciences Union (EGU). In the early 1960s, to facilitate decisions of executive government departments in meeting the rapidly increasing demand for industrial and domestic water supplies, a small Hydrological Research Unit (HRU) was established by the UK Department of Scientific and Industrial Research(DSIR) to investigate the comparative water use of forested and grassed upland catchments. These small beginnings in the HRU developed in a few years into the highly multi-disciplinary Institute of Hydrology (IH) as a source of independent advice for policy makers, with a capability to undertake longer term research, monitoring and data collection than was feasible in individual government departments or in the universities. Within IH, the range of specialities included not only engineering, physics, geography, geology, meteorology and instrumentation but also pollution, plant physiology, ecology, chemistry and economics. Said quickly in retrospect, the trajectory of the growth of IH seems smooth but, in reality, it masked many struggles between competing disciplines and departments before hydrology was recognised as a subject in its own right - the science of water.
\end{abstract}

Keywords: hydrological retrospective, catchment area water balances, land-use changes, physical and chemical processes, Institute of Hydrology, floods, droughts, forest micrometeorology, soil physics methodology

\section{Introduction}

The choice of the title "All our yesterdays" from Shakespeare's Macbeth seemed appropriate for a retrospective on hydrology, particularly if the quotation is continued: "have lighted fools the way to dusty death". Inevitably people come and go; likewise, organisations change, develop, thrive and then, perhaps, wither away. This is the case today. The Institute of Hydrology, the institution which fostered hydrology in its infancy in the UK, has now been slimmed down and combined with other institutes into a new organisation called the Centre for Ecology and Hydrology. So, however famous and successful any organisation may be and however great the personal contributions of many individuals, advances into the future depend not only on the integrity of the science and on the intellects of its practitioners but also on the actions of politicians and managers. It is to be hoped that hydrology and hydrologists have reached sufficient maturity in skills, numbers and recognition to prosper under very changed circumstances. At this time of change, I am most grateful for the opportunity to reflect on the growth of hydrology in which I have been privileged to take part. By its nature, science is forward looking but there is no sounder basis for future development than critical recognition of the legacy of the past.

In my working lifetime, I have been fortunate in the people I have met as colleagues and the opportunities which thus arose. I graduated in physics - then called natural philosophy - from the University of Edinburgh, alongside John Monteith, who is famous for his contributions to agricultural and hydrological research. Despite a warning from a university careers adviser that there was no longterm future in studies of the environment, I did doctoral research on soil physics and agricultural meteorology with Howard Penman at the Rothamsted Experimental Station, an internal college of London University, as well as a course in meteorology under P.A. Sheppard at Imperial College, London. Working within the RAF as a research and development scientist in the UK Ministry of Supply helped my understanding of men obliged to cooperate in strange tasks rather than in science. Thereafter, I travelled to Kenya to join Charles Pereira in setting up, long before the 
International Hydrological Decade, the East African Agriculture and Forestry Research Organisation (EAAFRO) catchment area experiments in Kenya, Uganda and Tanganyika. These countries were exciting environmentally, as well as somewhat hazardous because of the Mau Mau uprising in Kenya whilst all three East African countries were still ruled from London. Although both Penman and Pereira would claim to be physicists rather than hydrologists, the outstanding contributions to science of both lay in what is now called hydrology. Indeed, I consider that the greatest individual advance in hydrology in the $20^{\text {th }}$ century was Penman's solution of the water and heat balance equations in his famous estimate of evaporation (Penman, 1948); this, as well as other notable contributions to science, led to his being elected Fellow of the Royal Society of London (FRS). In a different style, Pereira's optimism and courage in overcoming obstacles to the formidable task of pioneering catchment experiments in developing countries was inspiring at a time when scientists were all too ready to beat a retreat from the field into the laboratory and the future promise of the computer screen. Pereira's work led, in 1966, to his being awarded the Haille Selassie Prize for Research in Africa and, in 1969, to his also being elected FRS.

In agricultural research in East Africa, where the objective was to make two blades of grass grow where one grew before, there was hydrology aplenty. Given only water, almost any crop could be grown; without it, very little. Hence, the hydrological consequences of changes in land use in East Africa's high altitude water catchment areas were so important for future development that the EAAFRO Division of Physics and Statistics became, largely, a Division dedicated to catchment area research. In the 1950s and 1960 s, instrumentation was basic; the only routine measurements were of rainfall, streamflow and, at a few sites, evaporation of water from a heavy steel pan about $1 \mathrm{ft}$ deep and $4 \mathrm{ft}$ in diameter, painted black internally and exposed above the ground on heavy baulks of timber. However, for research purposes, labour was plentiful so that soil moisture could be measured gravimetrically by routine sampling to $10 \mathrm{ft}$ depth in lateritic soils so deep that they are capable of storing a whole season's rainfall. Hence, long before sophisticated instruments had been developed to measure the more elusive components of the hydrological cycle, realistic water balances in research catchments could be drawn up from field measurements of rainfall, river flow and soil moisture. These, together with the Penman estimate of evaporation based on direct measurements of solar radiation, air temperature, air humidity and wind speed, enabled determination of the water balance in upland water catchments, the protection of which was so vital to the prosperity of the towns and agriculture downstream.
Except for a sabbatical year reading statistics-biometrics with David Finney at Aberdeen University, I spent the years 1955-1964 in East Africa, initiating and pursuing agricultural, meteorological and hydrological experimentation. This proved to be an ideal apprenticeship for a similar task in the UK in charge of the Department of Scientific and Industrial Research (DSIR) Hydrological Research Unit (HRU) and later the Institute of Hydrology (IH), from which I maintained my links with Kenya. Following the first report in a Special Issue of the East African Agriculture and Forestry Journal, (Pereira, 1962), the East African catchment studies were continued until 1974 under the guidance of IH staff from the UK (Edwards and Blackie, 1981; Blackie and Robinson, 2006).

\section{The Institute of Hydrology}

In 1964, following the independence of the East African countries, I returned to the UK as successor to Dr Eamonn Nash as Head of the HRU, a group of eight staff, housed in the attics of Howbery Park, the headquarters of the Hydraulics Research Station (HRS), then part of the Department of Scientific and Industrial Research. The initial task for the HRU, laid down by the DSIR Committee on Hydrological Research, was to resolve the controversy (Law, 1957) over the comparative water use of forest versus grassland in the catchment areas of UK upland reservoirs, the water from which was essential to so many cities.

Within a year, an incoming Labour government recognised that environmental research should be fostered away from the domination of traditional "hard" science and transferred the HRU to an embryo Natural Environment Research Council (NERC). Hopes were raised of new investment in hydrology to answer national concern about the effects of afforestation on catchment water yields. Pending a decision on the unit's ultimate location, we, John Sutcliffe, (later UK Floods Team leader), John Rodda, (later World Meteorological Organisation Director of Hydrology and Water Resources), John Bell, (soils), Lewis Shaw and Ann Hill (computing), Ian Strangeways (instrumentation) and Alan Bucknell (field worker) scoured the UK for matched pairs of potentially watertight forested and moorland/ grassland catchments. Eventually, the acid grassland headwaters of the Wye were chosen to compare with the adjoining forested headwaters of the Severn, both rivers rising on Plynlimon in mid-Wales. The plan was to initiate detailed catchment research which would facilitate government decisions on meeting the rapidly increasing demand for industrial and domestic water supplies.

The programme of research, published in the HRU Record of Research (Hydrological Research Unit, 1967) stretched 
far beyond the resources then available. But, driven by Prime Minister Harold Wilson's "white heat of the technological revolution", there was confidence in the ability of science, ultimately, to resolve all problems. Visitors to the HRU then, struck by the youth and enthusiasm of the staff, were even more impressed at the range of disciplinary backgrounds incorporated within the unit, now housed in a cluster of temporary wooden buildings. And when NERC decided that the HRU should be renamed the Institute of Hydrology (IH) with a new building on an adjoining site at Wallingford, the staff grew to over 150 in a few years. To the original disciplines in physics, mathematics, statistics, meteorology, physical geography and geology, as well as civil, hydraulic and electronic engineering, were added plant physiology, ecology, environmental chemistry, pollution and, eventually, economics. In retrospect, the trajectory might appear to have been smooth; in reality, it masked many struggles and interdisciplinary and inter-departmental disputes before hydrology was really established as a respected subject in its own right.

Even before the Plynlimon catchments were selected as the principal UK research catchments (later to become a national centre for field research in hydrology, used by staff and students of many British universities and by overseas visitors), preliminary investigations of techniques of measurement and analysis were based on a lowland catchment study on the River Ray at Grendon Underwood (Mandeville et al., 1970; Robinson and Rycroft, 1999). Later, in a catchment experiment at Coalburn in the northern Pennines, grassland was plough drained and planted to conifers (Robinson, 1998: Robinson et al.,1998), an urbanisation experiment was established at Milton Keynes and forested and moorland/grassland catchments were monitored in Perthshire at Balquhidder where snowfall is a larger proportion of annual precipitation than at Plynlimon (Calder, 1993). For all these field projects, networks for measurement of precipitation to an acceptable level of precision were researched (Rodda, 1970; Robinson and Rodda, 1969) while the challenging requirement for accurate measurement of flows in steep streams in upland catchments was satisfied by a successful development at HRS (Harrison and Owen, 1967). All these catchments were used to study the physical processes by which precipitation is converted into evaporation, runoff, soil moisture storage and groundwater recharge. Later, the need for better understanding of the effects of land use on water quality led to staff appointments in water chemistry and this has become a highly productive research group at Wallingford. (Neal, 1997; Neal et al., 1997, 2004)

Here, it would be impossible to give adequate acknowledgement to all the colleagues who propelled the
HRU into the vigorous and financially very viable Institute of Hydrology. After service in IH, quite a number of staff members moved onwards and upwards into an impressive range of international and national appointments as well as to academe in the UK, Ireland, USA and Brazil, often maintaining effective links and collaboration with IH. Others left to prosper in successful hydrological and environmental consultancies. Sadly, the demise of several most respected colleagues is mourned; all of them had made major contributions to the development, standing and capability of IH as an organisation.

Notwithstanding the terms of reference of the original Hydrological Research Unit to determine water balances of complete upland catchments under different land uses, it was obvious from the outset that, irrespective of the number and size of the catchments studied, it would be hazardous to predict, from the known performance of a few experimental catchments, the behaviour of others which had not even been monitored. Within the limits of error of the many measurements, a valid statistical result could be obtained, in time, from particular catchments, each in its own environmental and climatic situation. As a physicist, I saw the need for research into the physical processes underlying the results from studies of catchment systems and I endorsed the comment of Penman (1972) in his Foreword to the 1971-2 IH Record of Research, that a much more important result of the experiments would be to determine not just how an experimental catchment behaved but $\boldsymbol{w h y}$ it behaved as it did.

Achieving this understanding necessitated detailed studies of all the physical processes occurring within the catchments. These included interception of incoming precipitation by, and direct evaporation from the vegetation, to the infiltration of water into the soil and its subsequent movement and redistribution therein en route either to the stream as runoff or to the atmosphere as evaporation from the soil surface and as transpiration by the vegetation. In all such studies, it was necessary to understand and, ultimately, to measure evapotranspiration from the vegetation in the catchment; this is much more difficult to achieve over forest than over a short, agricultural crop because gradients of humidity within a forest are very small indeed. So the Physical Processes Division of IH flourished with a wide range of specialists in instrumentation, micrometeorology, plant physiology, soil physics and soil chemistry working in close collaboration with biologists, geologists, fluvial geomorphologists and physical geographers. One success was the micrometeorological measurement of evaporation and transpiration from a $30 \mathrm{~m}$ high pine forest near Thetford, Norfolk using the Bowen ratio energy balance approach; this made unique contributions to understanding of 
evaporation (Stewart and Thom, 1973; Thom et al., 1975; Stewart, 1977; Thom and Oliver, 1977; Stewart, 1988; Jarvis et al., 2007), coupled with a parallel study of rainfall interception (Gash 1979); these measurements gave new insight and understanding of the process of evaporation from forests. A linked outcome was the application of soil physics methodology to water balance measurement, originally at Thetford (Dolman et al., 1988) as well as under different environmental conditions in the UK and overseas (Cooper, 1979; Wellings and Cooper, 1983; Hodnett and Bell, 1986; Cooper et al., 1990). With the development of portable eddy correlation equipment (Lloyd et al., 1984; Shuttleworth et al., 1988), the experience gained at Thetford was later applied in Amazonia, where the first measurements of evaporation from tropical rainforest were made in 1983 (Shuttleworth et al., 1984; Shuttleworth, 1988). Building on this work, the ABRACOS project measured the effects of Amazonian deforestation on climate (Gash et al., 1996; Gash and Nobre, 1997). More recently, all the IH soil physical and chemical, plant physiological and water quality measurement techniques have been brought together within the NERC-funded LOCAR thematic programme (Wheater, 2006).

Too often in the past, rigid disciplinary structures have hampered genuine coordination of research efforts, even when the relevant scientists were based in the same building of the same organisation. The record of IH demonstrates not only the merits of building a truly interdisciplinary team 'in house' to address environmental problems central to hydrology but of maintaining close linkages at working level with sister organisations with interests in water analogous to those of IH. Thus, while, in principle, meteorology as a discipline might have pondered the propriety of IH studying rainfall measurement and micrometeorology, any possible disagreement was removed by establishing, at Wallingford, joint IH and Met Office teams for relevant research projects centred on hydrology. Similar solutions ensured close collaboration with ecology (particularly with Jack Rutter at Imperial College London and Paul Jarvis at the University of Edinburgh) and soil science at Reading University to good effect for all parties. However, proposals to integrate hydrology and hydrogeology within a single institute at Wallingford were opposed and finally rejected by professorial proponents of geology, who considered that, beyond the root range of the vegetation, infiltrating water became a geological rather than a hydrological variable! Similarly, early efforts to address water quality at IH were frustrated by the existence of a pollution laboratory at the Laboratory of the Government Chemist. Since, in some such situations, a top-down approach proved to be inappropriate, personal contacts between individual members of staff had to, and indeed often did, achieve at working level the collaboration and co-operation between their sciences which had eluded their masters.

In the UK in 1964, I had found that most available hydrological instruments had been designed in the $19^{\text {th }}$ century. Indeed, until the creation of the Water Resources Board in 1965, there was not even a national network of flow gauging stations so that engineers frequently had to produce designs for hydraulic structures based on flow estimates from rainfall measurements only. Moreover, it was then impossible to make routine determinations of the two most intractable components of the water cycle, evaporation, including transpiration and interception, and changes in soil moisture storage. Hence, from the outset, I assigned substantial resources to the development of instrumentation. Nowadays, these physical constraints have been resolved, successfully, by advances in instrumentation developed at, or sponsored by, IH. These included, among many others, the Wallingford Soil Moisture Neutron Probe (Bell, 1969), the IH Automatic Weather Station, (Strangeways and McCulloch, 1965; Strangeways and Smith, 1985; Strangeways 1986), the Hydra for direct measurement of evaporation (Shuttleworth et al., 1988), the solid state rainfall recorder (Turner and Brunsdon, 1977), the capacitance soil moisture probe (Dean et al., 1987; Bell et al., 1987), the Wiser river environmental monitoring station (Evans et al.,1997) and a simple and inexpensive instrument system for rainfall measurement (Hughes et al., 1993).

Research in the uplands differed from the more practical considerations of planners of water resources in the lowlands, who were interested in not just the quantity but also the quality of the water available for their purposes. Therefore, following an assessment of 20 years of water balance and physical process experimentation at Plynlimon (Kirby et al., 1991), attention was concentrated on determining and tracing the many pollutants present even in the 'pure' headwaters of the Rivers Wye and Severn. (Neal et al., 1990, 1997a). These detailed studies of water chemistry provide a baseline for judging water quality downstream; they clarified the role of shallow groundwater in catchments, the extent of 'old' water in river flows (Neal et al., 1990, 1997a) as well as the capture within the catchments of wet and dry airborne pollutants such as chloride, sulphate, bromide, iodine, rare earths and even chromium (Neal et al., 1997b). In research studies such as those at Plynlimon in the Welsh mountains, these problems can be resolved, given only sufficient staff effort in the field and in the laboratory. An appreciation of the fundamental importance of such investigations of catchment chemistry appeared in The Water Quality of Plynlimon (Neal, 1997). 
Advances in hydrological research depend not only on instrumentation but also on dedicated application of sophisticated mathematical and statistical tools to the environmental data obtained using this instrumentation, all backed nowadays by a computing power which was unimaginable in 1973. Yet, even in 1965, IH was in the forefront of advances in applying computing to hydrology; IH staff had their own PDP computer as well as access to mainframes elsewhere and subsequently operated a UNIVAC 1108 mainframe in three shifts over 24 hours for maximum utility of the hardware.

Development of sensors has enabled the measurement of the various physical and chemical variables for an understanding of the fate of water on the earth's surface; given reliable instrumentation, the need for its care and maintenance thereafter is obvious. Studies of complete hydrological systems require continuity in monitoring of the many hydrological and hydrochemical variables which are representative of the system over a time period long enough to characterise the climate or the particular phenomenon being studied. Of course, all data must be the subject of painstaking scrutiny for quality control, which can be a major task in itself. To some researchers, the hydrological year may seem a long time to make measurements, perhaps in remote and/or inhospitable locations. Too often, papers submitted to conferences, seminars and even to scientific journals, are based on measurements over days or weeks rather than the months or years really needed to reach definitive conclusions. Monitoring for catchment area research imposes the longest time frame of all; new truths may be revealed after 10, 20, 30 or 40 years as the tree cycle runs from pre-planting through planting, growth, maturing, aging, felling and clearing (McCulloch and Robinson, 1993). Indeed, genuine conclusions from one decade of catchment research may well be reversed by the equally genuine results from the following decade (Marc and Robinson, 2007). At the same time, intensive measurements of physical and chemical variables are essential if the how and why of the catchment results are to be recognised and extrapolated. Overall, however sophisticated the instrumentation and computing facilities, there is no substitute for the presence of the researcher in the field. This can avoid conclusions from small scale local studies being over-emphasised and short-term results being extrapolated to different times, environments or climates in the absence of a full appreciation of the effect of the multiplicity of environmental variables and feedbacks. Theory and empiricism must go hand in hand, despite the expense and patient labour involved in the necessary field work. All this is a caveat against a reputed former attitude towards rapid, efficient, catchment (or watershed, as they would say in the USA) research; "Install a rain gauge and a flume or weir in a forested catchment and then calibrate, cut and publish."

\section{Floods, droughts and consultancies}

So far, this paper has concentrated largely on aspects of the IH programmes central to the View from the Watershed theme. However, IH was an institute with a balanced programme concerned with all manner of hydrological problems, including studies of floods and droughts as well as a wide diversity of consultancies, often on problems overseas. In 1970, concerns about the possible effects of flooding on the national economy led to the UK Flood Study, led by John Sutcliffe at IH. A team of 15 very able people was added to the Institute's complement, to estimate flood frequency in both gauged and ungauged catchments in the whole of the UK and Ireland. The five volume report, (NERC, 1975), was well-received by the hydrological community and was the basis of professional advice by the UK Institution of Civil Engineers (ICE) at the Flood Studies Conference held at the Institution in London in that year.

After the publication of the Flood Studies Report, IH responded to many requests in the 1970s and 1980s for advice on potential applications of FSR methodology to flood estimates, particularly in Africa, in the Middle-East and in S.E. Asia. Subsequently, IH analysed flood flow data from over 70 countries worldwide and published the results in papers aimed at practising engineers (Green et al., 1983; Farquharson et al., 1987, 1992, 1993; Meigh et al., 1993, 1997; Sutcliffe and Farquharson, 1998). Later, through UNESCO, the approach was extended internationally through the FRIEND (Flows from international experimental and network data) initiative involving $\mathrm{IH}$, European and international staff(Gustard et al., 1987, 1992). The value of the expertise at IH was recognised by many firms of consultants who, together with international agencies and national government departments, provided a valuable source of income both to sustain further IH growth and to maintain the necessary links between academic research and field practice.

When a further tranche of 25 years' UK hydrological data became available, the FSR was revised, using the extended data set and new developments in statistical methods. The Flood Estimation Handbook (FEH) (Institute of Hydrology, 1999) was likewise well received and commended. However, at an international conference in Beijing, I was perturbed to learn of the profound concern of engineers that a flood with a return period of 1-in-7000 years according to the 1975 FSR, was rated as a 1-in-1500 year storm in the $1999 \mathrm{FEH}$. Bearing in mind the extent of the extrapolation, 
initially from a data set of only 30 years and later of 55 years, I felt that the agreement was reasonable and the difference of a factor of five was entirely acceptable. Sadly, however, insurers and loss adjusters, interested only in exact estimates of the potential magnitude of extreme floods, were deaf to scientific explanations of the significance of the differences. Hence, reservoir authorities have been burdened with raising structures to satisfy each extreme prediction which, in consequence of global warming, may well become even more extreme in the future.

Following the completion of the FSR in 1975, research priorities were broadened to the opposite extreme, so droughts were investigated. Using many of the statistical techniques and national data sets established in the flood research, a national Low Flow Study was completed (Institute of Hydrology, 1980); this provided comprehensive design methods for estimating the frequency of low flows at ungauged sites. More detailed research included estimating the effect of lochs (lakes) on low flows in Scotland (Gustard et al., 1987). This was followed by a complete revision of the national design methodology for low flows. This benefited from a national study of the Hydrology of Soil Types (HOST) (Boorman et al.,1995), which reduced the uncertainty in flow estimated at ungauged sites. Applications of this research included the calculation of the dilution of effluent discharges, the licensing of abstractions for public water supply and the estimation of small hydropower potential. High demand for these research outputs led to the development of LOW FLOW 2000 (Young et al., 2003); this is now the industry-standard software for low flow design in the UK and incorporates a new region of influence approach in the prediction model (Holmes et al., 2002). In parallel with these UK developments, low flow research was undertaken as $\mathrm{IH}$ consultancies throughout mainland Europe, Malawi, Philippines, India and Nepal.

In the 1990s, a new driver for research was to estimate the effect of abstractions on in-stream ecology; this initiated a major and ongoing co-operation between hydrologists and ecologists focusing on the development, refinement and calibration of in-stream flow models. Severe droughts in the UK in 1975/1976, 1984, 1988-1992 (Bryant et al., 1994), 1998/1999, 2003 (UNEP, 2003) and 2005/2006 are reported in occasional publications of the Wallingford-based UK National Water Archive of rainfall, river flow and ground water levels (Lees, 1987). Using these data, a study of UK trends in low flows is summarised in Hannaford and Marsh (2005).

In addition, IH staff members have advised on a wide range of overseas water resource assessment or management studies, ranging from the first major water resources assessment of northern Oman, through enhancement of water supplies to Tehran, to improving the water supplies to Mogadishu in Somalia and Gaborone in Botswana. In more than four decades, IH staff acted as consultants in over 60 countries around the world (Acreman and Farquharson, 1992). However, as IH was funded in part through NERC by the various government departments responsible for funding civil science, it was never considered appropriate for externally-funded studies, however relevant to the research objectives of the Institute, to absorb more than 50\% of IH staff effort.

Historically, the acceptance of hydrology within government ensured a source of independent advice for policy makers coupled with the possibility of longer term research, monitoring and data collection than was feasible within the universities. Of course, none of this would have been achieved without a supply of well-trained and ambitious scientists stimulated by new ideas from university researchers. In the early days, only three universities in Britain - Imperial College London, Birmingham and Newcastle - offered Masters degree courses in hydrology but, as national and international interest in water increased, so the number of university researchers expanded rapidly. The Institute of Hydrology became a national focus for hydrology, concerned with encouraging and supporting hydrological research anywhere in the UK. Hydrology benefits enormously from international connections linking scientists with interests in common and a huge range of environments to investigate. Many eminent scientists from overseas chose to spend sabbatical years at Wallingford and the example of IH as a multidisciplinary organisation, open to new ideas and challenges, contributed to the growing acceptance and recognition of hydrology as a science rather than just as a sub-group of civil engineering or geography.

Over two decades elapsed from the creation of the HRU to the foundation in the UK of a learned society devoted to hydrology. The British Hydrological Society, created in 1984, is the intellectual home of all those involved in UK hydrology irrespective of their basic scientific discipline. Of course, similar societies exist in many countries and the Nordic Hydrological Association is very well known. But for Europe overall, the final accolade was the formal acceptance, by the European Geophysical Society at its Annual Assembly in Copenhagen in 1990, of hydrology as a science in its own right, dealing with all the processes of water.

\section{Hydrology and Earth System Sciences}

When, within EGS, hydrology was acknowledged as a major subject area, the hydrological research journal recognised initially by EGS, was the Elsevier Journal of Hydrology, of 
which I had been a Managing Editor since 1983. Boosted by Special Issues based on EGS symposia, with appropriate EGS convenors acting as Guest Editors, the annual number of volumes rose to 13 but delays in publication of papers, already edited and accepted, became considerable. Finally, these publishing delays and the substantial costs of journal subscriptions led to the EGS decision to found its own journal Hydrology and Earth System Sciences (HESS), publishing both regular scientific papers and themed Special Issues.

As the founding editor of HESS, now in the $11^{\text {th }}$ year of publication, I commend the effective support of the authors and scientific editors whose integrity, diligence and competence ensured that HESS was cited by the Institute for Scientific Information from its second year of publication, probably because the highest standards of peer reviewing were established from the outset and maintained thereafter. Initially, the journal appeared quarterly but, as HESS gained in popularity, so publication was increased to six Issues a year which permitted inclusion of up to three themed Special Issues.

\section{But what of the future?}

Water is the most remarkable and versatile element in life on Earth. However much water is misused, polluted or wasted, it cannot be destroyed and eventually returns relatively pure as precipitation, albeit at a different location. It is to be hoped that scientists' respect for the miracle of water will also prove indestructible. Climate change and more extensive human activities will stimulate new challenges, investigation of the hydrological consequences of which is central to the terms of reference of the former Institute of Hydrology. Over more than 30 years, it built up an international reputation for competence in studies of catchment areas, floods, droughts, environmental chemistry and water pollution, soil physics and agricultural meteorology as well as in development of instrumentation and statistical and computational techniques. These are applicable not only to research in the first instance but, after appropriate testing, to routine investigations of particular hydrological problems by technicians (McCulloch, 1988). Thus, the research endeavours of the past become the textbook material of the present and the technology of the future.

The challenges for today's young hydrologist are as exciting as ever they have been. While the investigation of the hydrological consequences of changes in land use in the uplands, the raison d'etre of the original Hydrological Research Unit, has largely been completed, extension of the results internationally will stress the vital role of forest in ensuring soil stability in headwater catchments, notwithstanding the water use of the forest cover (Calder, 1979); increasing water yield by forest removal is generally a short-term but unwise solution. Vastly improved instrumentation for sensing, logging and transmitting hydrometric measurements already facilitates retrieval of information from the far corners of the Earth's surface, while readily available computers provide undreamed of capabilities for manipulation of the data and modelling of the system. Increased awareness of water quality problems, highlighted by concerns over acid streams and nitrates in groundwater, has led to greater public appreciation of the inherent value of drinking water of good quality, in the provision of which hydrological research is of increasing importance. In the developing world, a phase of major developments centred on large scale projects is giving way to environmental protection and rehabilitation; it is increasingly being recognised that water resources development has often been undertaken with inadequate regard for the stability of the ecosystem. Clearly, requirements for innovative research hydrologists and for well-trained skilled technicians have never been greater and the loss of an internationally-recognised Institute of Hydrology is to be deplored.

\section{References}

Acreman, M.C. and Farquharson, F.A.K., 1992. Flood frequency of the world's largest catchments. Proc. 3rd International Conference on Floods and Flood Management, Florence, Italy. Kluwer, Dordrecht, The Netherlands. 145-156.

Bell, J. P., 1969. A new design principle for neutron soil moisture gauges: the 'Wallingford' Neutron Probe. Soil Sci., 108, 160164

Bell, J.P., Dean, T.J. and Hodnett, M.G., 1987. Soil moisture measurement by an improved capacitance technique, Part II. Field techniques, evaluation and calibration. J. Hydrol., 93, 7990.

Blackie, J.R. and Robinson, M., 2007. Development of catchment research with particular attention to Plynlimon and its forerunner, the East African catchments. Hydrol. Earth Syst. Sci., 11, 26-43.

Boorman, D.B., Hollis, J.M. and Lilly, A., 1995. Hydrology of soil types: a hydrologically-based classification of the soils of the United Kingdom, IH Report No. 126. Institute of Hydrology Wallingford, UK. ISBN $0948540699137 \mathrm{pp}$

Bryant, S.J., Arnell, N.W. and Law, F.M., 1994. The 1988-92 drought in its historical perspective. J. Inst. Water Eng. Manage., 8, 39-51.

Calder, I.R., 1979. Do trees use more water than grass? Water Services, 83, 11-14.

Calder, I.R., 1993. The Balquhidder catchment water balance and process experiment results in context; what do they reveal? $J$. Hydrol., 145, 467-477.

Cooper, J.D., 1979. Water use of a tea estate from soil moisture measurements. E. Afr. Agr. Forest. J., 43, (Special Issue), 102121. 
Cooper, J.D., Gardner, C.M.K. and Mackenzie, N., 1990. Soil controls on recharge to aquifers. J. Soil Sci., 41, 613-630.

Dean, T.J., Bell, J.P. and Baty, A.J.B., 1987. Soil moisture measurement by an improved capacitance technique, Part I. Sensor design and performance. J. Hydrol., 93, 67-78.

Dolman, A.J., Stewart, J.B. and Cooper, J.D., 1988. Predicting forest transpiration from climatological data. Agr. Forest. Meteorol., 42, 339-353.

Edwards, K.A. and Blackie J.R., 1981. Results of the East African catchment experiments, 1958-74. In: Tropical Agricultural Hydrology, R. Lal and E.W. Russell (Eds.) Wiley, New York, USA. $163-188$.

Evans, J.G., Wass, P.D. and Hodgson, P., 1997. Integrated continuous water quality montoring for the LOIS river programme. Sci. Total Envir., 194/195, 111-118.

Farquharson, F.A.K., Meigh, J.R. and Sutcliffe, J.V., 1992. Regional flood frequency analysis in arid and semi-arid areas. J. Hydrol., 138, 487-501.

Farquharson, F.A.K., Meigh, J.R. and Sutcliffe, J.V., 1993. Charactéristiques de la crue régionale en Afrique de l'Ouest. Hydrologie Continentale, 8, 3-16.

Farquharson, F.A.K., Green, C.S., Meigh, J.R. and Sutcliffe, J.V., 1987. Comparison of flood frequency curves from many different regions of the world. In: Regional Flood Frequency Analysis, V.P Singh (Ed.). Reidel, Dordrecht, The Netherlands. 223-256.

Gash, J.H.C., 1979. An analytical model of rainfall interception in forests. Quart. J. Roy. Meteorol. Soc., 105, 43-55.

Gash, J.H.C. and Nobre, C.A., 1997. Climatic effects of Amazonian deforestation: some results from ABRACOS. Bull. Amer. Meteorol. Soc., 78, 823-830.

Gash, J.H.C., Nobre, C.A., Roberts, J.M. and Victoria, R.L. (Eds), 1996. Amazonian Deforestation and Climate. Wiley, Chichester, UK.

Green, C.S., Boorman, D.B. and Farquharson, F.A.K., 1983. Flood design manual for Java and Sumatra, 2 Volumes. Institute of Hydrology, Wallingford, UK and the Government of the Republic of Indonesia, Jakarta, Indonesia.

Gustard, A., Marshall, D.C.W. and Sutcliffe, M.F., 1987. Low flow estimation in Scotland. IH Report No. 101, Institute of Hydrology, Wallingford, UK. 29pp.

Gustard, A, Bullock, A. and Dixon, J.M., 1992. Low flow estimation in the UK. IH Report No. 108. Institute of Hydrology, Wallingford, UK. ISBN 09485400451 88pp plus Appendices

Hannaford, J. and Marsh, T., 2005. An assessment of trends in UK runoff and low flows using a network of undisturbed catchments. Int. J. Climatol., 26, 1237-1253.

Harrison, A.J.M. and Owen, M.W. 1967. A new type of structure for flow measurement in steep streams. Proc. Inst. Civil Eng., 36, 273-296.

Hodnett, M.G. and Bell, J.P., 1986. Soil moisture investigations of groundwater recharge through black cotton soils in Madhya Pradesh, India. Hydrolog. Sci. J., 31, 361-381.

Holmes, M.G.R., Young, A.R., Gustard, A. and Grew, R., 2002. A region of influence approach to predicting Flow Duration Curves within ungauged catchments. Hydrol. Earth Syst. Sci., 6, 721-731.

Hughes, C., Strangeways, I.C. and Roberts, A.M., 1993. Field evaluation of two aerodynamically-profiled raingauges. Weather, 48, 66-71.

Hydrological Research Unit, 1967. Record of Research. Wallingford, UK. 43pp.

Institute of Hydrology, 1980. Low flow Study Report. Institute of Hydrology, Wallingford, UK. 3 volumes.
Institute of Hydrology, 1999. Flood Estimation Handbook. Institute of Hydrology, Wallingford, UK. 5 volumes ISBN 09485094

Jarvis, P.G., Stewart, J.B. and Meir, P., 2007. Fluxes of carbon dioxide at Thetford Forest. Hydrol. Earth Syst. Sci., 11, 245255.

Johnson, P., 1981. The future of flood estimation and the Flood Studies Report. Proc. Inst. Civil Eng., Pt. 1, 70, 833-843.

Kirby, C., Newson, M.D. and Gilman, K. (Eds.), 1991. Plynlimon research: the first two decades. IH Report No. 109, 188pp. ISBN 0948540273

Law, F., 1957. Measurement of rainfall, interception and evaporation losses in a plantation of Sitka Spruce trees. IAHS Publication no. 44, 397-411.

Lees, M.L., 1987. Inland Water Surveying in the UK - a short history. In: 1985 Year Book Hydrological Data UK. Institute of Hydrology, Wallingford, UK. 35-47.

Lloyd, C.R., Shuttleworth, W.J., Gash, J.H.C. and Turner, M., 1984. A microprocessor system for eddy correlation. Agr. Forest Meteorol., 33, 67-80.

Mandeville, A.N., O'Connell, P.E., Sutcliffe, J.V. and Nash, J.E., 1970. River flow forecasting through conceptual models: Part III - the Ray catchment at Grendon Underwood. J. Hydrol., 11,109-128.

McCulloch, J.S.G., 1988. Hydrology - science or just technology? Record of Research 1984 - 87. Institute of Hydrology, Wallingford, UK. i-ii.

McCulloch, J.S.G. and Robinson, M. 1993. History of forest hydrology. J. Hydrol., 150, 189-216.

Mandeville, A.N., O'Connell, P.E., Sutcliffe, J.V. and Nash, J.E., 1970. River flow forecasting through conceptual models: Part III - the Ray catchment at Grendon Underwood. J. Hydrol., 11, $109-128$.

Marc, V. and Robinson, M., 2007. The long-term water balance (1972-2004) of upland forestry and grassland at Plynlimon, midWales. Hydrol. Earth Syst. Sci., 11, 44-60.

Meigh, J.R., Farquharson, F.A.K. and Sutcliffe, J.V., 1993. Prediction of flood risk in developing countries with sparse river flow data. In: Natural Disasters: Protecting Vulnerable Communities, P.A. Merriman and C.W.A. Browitt, (Eds.) Thomas Telford, London, UK. 315-330.

Meigh, J.R., Farquharson, F.A.K. and Sutcliffe, J.V., 1997. A worldwide comparison of egional flood estimation mthods and climate. Hydrolog. Sci. J., 42, 225-244.

Neal, C., 1997. The water quality of the Plynlimon catchments (UK). Hydrol. Earth Syst. Sci. Special Issue, 1, 381-764.

Neal, C., Ormerod, S.J., Langan, S.J., Nisbet, T.R. and Roberts, J., 2004. The water quality functioning of the upper River Severn, Plynlimon, mid-Wales: issues of monitoring, process understanding and forestry. Hydrol. Earth Syst. Sci., 8, 277595.

NERC, 1975. Flood Studies Report. Natural Environment Research Council. London, UK. 5 Volumes. ISBN 094854050

Penman, H.L., 1972. Foreword to IH Record of Research, 1971-2. Institute of Hydrology Wallingford, UK.

Penman, H.L., 1948. Natural evaporation from open water, bare soil and grass. Proc. Roy. Soc. Lond., A 193, 120-145.

Pereira, H.C., 1962. E Afr. Agr. Forest. J., 27, Special Issue. 131pp.

Robinson, M., 1998. 30 years of forest hydrology changes at Coalburn: water balance and extreme flows. Hydrol. Earth Syst. Sci., 2, 233-238.

Robinson, A.C. and Rodda, J.C., 1969. Rain, wind and the aerodynamic characteristics of raingauges. Met. Mag., 98, 113120. 
Robinson, M. and Rycroft, D.W., 1999. The impact of drainage on streamflow. Chapter 23 in : Agricultural Drainage, W.Skaggs and J.van Schilfgaarde (Eds.) Agronomy Monograph 38. American Society of Agronomy, Madison, Wisconsin. USA.753-786.

Robinson, M., Moore, R.E., Nisbet, T.R. and Blackie, J.R., 1998. From moorland to forest: the Coalburn catchment experiment. IH Report 133. Institute of Hydrology, Wallingford, UK. 64pp. ISBN 0948540869.

Rodda, J.C., 1970. On the question of rainfall measurement and representativeness. Proc IAHS Symposium World Water Balance. IAHS publication no. 174-186.

Shuttleworth,W.J., 1988. Evaporation from Amazonian rain forest. Proc. Roy. Soc. Lond. B, 233, 321-346.

Shuttleworth, W.J., Gash, J.H.C., Lloyd, C.R., McNeil, D.D., Moore C.J. and Wallace, J.S., 1988. An integrated micrometeorological system for evaporation measurement. Agr. Forest Meteorol., 43, 295-317.

Shuttleworth, W.J., Gash, J.H.C., Lloyd, C.R., Moore, C.J., Roberts, J., Marques, A. de O., Fisch, G., Silva, V. de P., Ribeiro, M.N.G., Molion, L.C.B., de Abreu Sa, L.D., Nobre, C., Cabral, O.M.R., Patel, S.R. and de Moraes, J.C., 1984. Eddy correlation measurements of energy partition for Amazonian forest. Quart. J. Roy. Meteorol. Soc., 110, 1143-1162.

Stewart, J.B., 1977. Evaporation from the wet canopy of a pine forest. Water Resour. Res., 13, 915-921.

Stewart, J.B. and Thom, A., 1973. Energy budgets in pine forest. Quart. J. Roy. Meteorol Soc., 99, 154-170.

Strangeways, I.C., 1986. The development of an automatic weather station for arctic regions. PhD thesis, University of Reading, UK
Strangeways, I.C. and McCulloch, J.S.G., 1965. A low-priced automatic hydro-meteorological station. Bull. Int. Assoc. Sci. Hydrolog., X, 57-62.

Strangeways, I.C. and Smith, S.W., 1985. Development and use of automatic weather stations. Weather, 40, 277-285.

Sutcliffe, J.V. and Farquharson, F.A.K., 1998. Flood frequency studies using regional methods. In: Statistical and Bayesian Methods in Hydrological Sciences, E. Parent, P. Hubert, B. Bobée and J. Miquel (Eds.),Technical Publication No. 20, UNESCO, Paris, France. 341-356.

Thom, A. S. and Oliver, H.R., 1977. Penman's equation for estimating regional evaporation. Quart. J. Roy. Meteorol. Soc., 103, 345-357.

Thom, A.S., Stewart, J.B., Oliver H.R. and Gash, J.H., 1975. Comparison of aerodynamic and energy balance estimates of fluxes over a pine forest. Quart. J. Roy. Meteorol. Soc., 101, 93-105.

Turner, M. and Brunsdon, G.P., 1978. Solid state event recorder for rainfall measurement. Hydrolog. Sci. Bull., 23, 143-149.

UNEP, 2003. Impacts of summer 2003 heatwave in Europe. DEWA/Europe/GRID-Geneva.www.grid.unep.ch/activities/ earlywarning/preview/appl/climatic/images/heatwave_en.pdf

Wellings, S.R. and Cooper, J.D., 1983. The variability of recharge of the English Chalk aquifer. Agr. Water. Manage., 6, 243-253.

Wheater, H.(Ed.) et al., 2006. Hydro-ecological functioning of the Tern, Frome and Lambourne catchments, UK- results from the LOland CAtchment Research (LOCAR) initiative. $J$. Hydrol., 330 (in press)

Young, A.R., Grew, R. and Holmes, M.G.R. 2003. Low Flows 2000: a national water resources assessment and decision support. Water Sci. Technol., 48, 119-126. 